\title{
Walkable Streets: A Study of Pedestrians' Perception, and Attitude towards Ngei Street in Machakos Town
}

\author{
Julianne Kinyingi*, Njuguna Mugwima, Dennis Karanja \\ Centre for Urban Studies, Jomo Kenyatta University of Agriculture and Technology, Nairobi, Kenya \\ Email: ^jnkinyingi@gmail.com
}

How to cite this paper: Kinyingi, J., Mugwima, N., \& Karanja, D. (2020). Walkable Streets: A Study of Pedestrians' Perception, and Attitude towards Ngei Street in Machakos Town. Current Urban Studies, 8, 381-395.

https://doi.org/10.4236/cus.2020.83021

Received: May 26, 2020

Accepted: August 17, 2020

Published: August 20, 2020

Copyright $\odot 2020$ by author(s) and Scientific Research Publishing Inc. This work is licensed under the Creative Commons Attribution International License (CC BY 4.0).

http://creativecommons.org/licenses/by/4.0/

(c) (i) Open Access

\begin{abstract}
Street walkability is an indication of the suitability of the built environment to walking. Walkability of any street will increase when safe, comfortable and accessible infrastructure is provided for pedestrians. Urban designs influence how an individual perceives the built environment, including the desirability of walking and all other physical activities involved. Three street factors (accessibility, congestion and cleanliness) along a 900 meters long central segment of Ngei Street in Machakos Town were directly measured by use of standardized questionnaires. The number of pedestrians in the segment was estimated using Fischer's formula and 96 of them where sampled using judgmental technique. Majority (51\%) of pedestrians who responded to the questionnaire indicated that the street was wide enough and accessible while $12 \%$, $15 \%, 3 \%$ and $17 \%$ strongly agreed, disagreed, neutral and agreed respectively. In addition, the results revealed that densities of movement increase with increased width of the walkways. With little consideration of pedestrians and other road users' this has led to high congestion in Ngei Street which was affirmed by $47 \%$ of the majority respondents. Lastly, $56 \%$ of the respondent confirmed that the Ngei Street (understudy) was well maintained and clean. This study recommends improvement and addition of non-continuous pedestrian walkways, designation of pedestrian crossing across all street segments to ease traffic management and reduce vehicle congestion in addition to periodic walkways maintenance and regular pavement cleaning.
\end{abstract}

\section{Keywords}

Street Walkability, Built Environment, Pedestrian, Desirability, Cleanliness and Maintenance 


\section{Introduction}

Walking is one of the simplest and least costly forms of physical activity (Gehl, 2013). Walking keeps people healthy; and can help prevent, among others, heart disease, diabetes, hypertension, and obesity (Gehl, 2013; Hass-Klau, 2014). Walking also encourages social contact among people, thereby improving their mental health and wellbeing (Shaaban, 2019). Street walkability is an indication of the suitability of how amenable the built environment is for walking. A walkable street is a street where walking is safe and pleasant, where people are attracted to walk and where fast and extensive car traffic is not a priority (Quednau, 2018). Walkability of any street will increase when safe, comfortable, and accessible infrastructure is provided for pedestrians (Litman, 2016). Proper design construction of a walking environment is critical factor in promoting walkability as they result in more attractive, convenient, healthier, and efficient streets (Quednau, 2018). The importance of walkable streets has been confirmed by several studies across the World (Litman, 2016; Quednau, 2018; Shaaban, 2019).

As with any other human behavior, Mehta (2008) notes that walking is primarily influenced by cultural factors, individual circumstances, preferences, and environmental factors. Additionally, environmental factors that influence walking along cities include compactness of development patterns, residential density, and land-use mix. Design features such as shade, scenery, local environment aesthetics, local shopping, retail distance, and the presence of attractive shops and houses also influence street walkability (Mehta, 2008). Pavements are the principal pedestrian mobility infrastructure. Although considerable attention has been given in different countries to studying the condition of the pavements and their impact on walkability, there are few studies in developing countries investigating walkable streets (Shaaban, 2019).

Walkable cities afford many advantages to their citizens in terms of road and personal safety, convenience, accessibility to destinations, combined transport, and a higher level of health (Athanasios et al., 2016). Urban designs influence how an individual perceives the built environment, including the desirability of walking or other physical activity. The built environment plays a crucial role in physical activity and may either improve opportunities or hamper them (Coughenour, 2013). Some of the urban design features that influence perception and walkability include among others, building orientation and setback; block length; building height and street enclosure (aspect ratio); and, building scale and variety. Furthermore, walking also affects factors such as income, individual preferences, cultural values, and climate. Depending on this characteristic, the same place may be more or less walkable or have more or less actual walking (Forsyth, 2015).

Pedestrian perceptions have great significance in the evaluation process of the street environment. In order to identify and create a safe and desirable walking environment, the pedestrians are the most appropriate group to assess their perception, knowledge, and attitude towards the streets (Sisiopiku \& Akin, 2003; 
Chu, Guttenplan, \& Baltes, 2004; Mehta, 2008). Perceptional characteristics increase the pleasure of walking by stimulating exploratory activity (Wang, Li, Wang, \& Namgung, 2012). Personal safety is one of the pedestrian concerns when using a pedestrian walkway against adjacent traffic (Montgomery, 1998). Image is comprised of a person's beliefs, ideas, feelings, expectations, and impressions about a place (Lynch, 1960). Street activities are the determinants of the perceptions of people on the street environment and contribute to an individual's image of a street. This perhaps hints why individuals are fond of certain conditions of the street environment and enjoy walking or activities around certain streets (Mehta, 2008). Therefore, street image can be conceived as a combination of a particular identity and how a place is perceived (feelings and impressions). This means that images of place are created from amalgamations of cognition (comprehension or understanding) and perceptions, as well as individual's, group's, and cultural “personality” constructs or meaning (Lynch, 1960; Montgomery, 1998).

Perception studies about city streets are particularly important as they inform decision-makers on what people think of streets; is a street pleasant and attractive, safe and lively, clean, and does it encourage people to carry out activities that they like? The integration between street characteristics and street activities, that is, morphology and performative aspects, leads to the achievement of a distinct kind of street environment (Tibbalds, 2012). Important factors that affect perception include the safety of pedestrians, aesthetics, and amenities. These factors are important regardless of the pedestrian travel purpose and impact leisure and other activities that go in hand with the street use. Better aesthetics attract various activities other than perception on the streets (Cho, Rodríguez, \& Khattak, 2009; Bahari, Arshad, \& Yahya, 2013).

Machakos town is located in East Central of Kenya and was the first state capital from 1895 to 1899 . From then, the town has evolved to be the administrative centre for former Machakos district, and its current headquarters for Machakos County. The transportation system in Machakos Town is facing problems resulting in heavy pressure on existing transportation infrastructure, low-quality, non-motorized transportation infrastructure, traffic safety issues, coordination issues between various public agencies, and a shortage of experienced transportation professionals for management, planning, and operation. Incentives for walking are, in many cases limited, since the pavements either has problems (obstructed, too narrow, and dirty) or, in some cases, may not even be provided. Ngei Street is the busiest street in Machakos town. In particular, it is typified by uncoordinated parking on sidewalks and visual clutter from uncontrolled advertisements and signage as well as clogged drainage that does not enhance the visual quality of the street.

An appropriate indicator for assessing the level of walkability of an urban street is to examine the use of the street by pedestrians. Improving foot safety, mobility, and convenience is an important step towards promoting sustainable 
mobility in urban areas. In this study three factors were examined: Accessibility which includes a person's ability to access the destination; distances to a destination; physical and perceived barriers to walking to a place; and connectivity between uses of land (measured using the following indicators; walkway width, broken paving surface, obstacle by utility poles, uneven level changes, and feeder roads), congestion (indicators are hawkers activities, encroached walkways by stalls and shared pedestrian and parking bay) and cleanliness (indicators entail obstacle by construction materials, cleanliness of pedestrian walkway and waterlogging). Lastly, the results of this study will inform, enhance, and aid in the decision-making process in Machakos County with respect to urban planning and design of street environments and elsewhere in the World.

\section{Theoretical Framework}

Social life requires making inferences about people because of the complex nature of social experiences. An accurate impression of how individuals feel serves a fundamental purpose of allowing researchers to predict people's rational thoughts, feelings, and actions (Thornton \& Mitchell, 2018). Moreover, the need to understand other people's perceptions raises questions on how their minds spontaneously organize their perception into more useful, coherent models of other individuals (Demuth, 2013; Thornton \& Mitchell, 2018). Demuth (2013) highlights the need to study people's perception based on the first mediation of Meditations on First Philosophy by Rene Descartes, which underlie the importance of understanding our senses and how human brains works. Numerous theories and concepts to understand human perception including: the bottom-up theories (Demuth, 2013), Gibson's theory of direct perception (Costall \& Still, 1989; Gibson, 2014), Constructivists theories (Bodner, 1986; Barkin, 2003; Fosnot, 2013), Gregory's theory (Demuth, 2013) and Computational theories (Ramachandran, 1990; Shapley et al., 1990; Knill \& Grossberg, 1996), among others.

However, this paper is built on Gibson's theory of direct perception that is found on the cognitive apparatus that was created and formed by long evolutionary influences of the external environment that are clear in structure and abilities (Costall \& Still, 1989; Gibson, 2014). The theory asserts that humans learn to extract information, which is critical for their survival. Drawing from Darwin's assumption, "the pressures of the environment are caused by human receptors to be created and formed so that they can be sensitive to relevant stimulus from the environment, and they are adapted to the environment (Demuth, 2013: p. 24).” Such an interpretation of perception is referred to as ecological because it attributes the determinative role of the environment as well as their influence on the whole process of perception (Demuth, 2013). On the basis of Gibson's theory is the fact that human perception is determined by optic flows-sorts of structures or patterns of light in the environment. Gibson argued that a human perceives objects (their sensory qualities) in a way by which packets of information enter their 
sensors. This can mean that "an observer is more or less a passive space into which information coming from the environment is being imprinted (Demuth, 2013: p. 24)." Moreover, Gibson believed that the central part of the information contained in information beams around human is invariant and as such, people perceive realities independently, and from a perspective, they can capture the world (Johansson, 1970; Reed, 1988; Robbin, 2000; Demuth, 2013; Gibson, 2014).

\section{Material and Methods}

\subsection{Description of the Study Area}

The town of Machakos is located between longitudes $37^{\circ} 22^{\prime}$ and $37^{\circ} 08^{\prime}$ East and latitudes $1^{\circ} 38^{\prime}$ and $1^{\circ} 22^{\prime}$ South. The town is situated about $70 \mathrm{kms}$ south-east of Nairobi, Kenya's capital city on a plain $1000 \mathrm{~m}$ above sea level (Machakos CIDP 2018-2022, see Figures 1-3). This study was conducted in Ngei Street (the busiest street in Machakos Town) as indicated in Figure 4(a). One 900 meters long segment of Ngei Street was selected from the commercial and part residential area of Machakos Town. The area of study was composed of three segments of the Ngei Street and for each segment of the street, the built environments were identified with codes as in Figure 4(b).

\subsection{Sampling and Sampling Procedures}

The target population consisted of Machakos Town community, which comprised people from various regions and counties (For this study, it was a challenge to have a specific target population because the street is used by various people of all walks of life and they may not necessarily be Machakos County residents). A judgmental sampling was employed to get the sample size of 96 pedestrians and randomly interviewed. To determine the appropriate sample size, Fisher's formula was used. The researcher assumed a 95\% desired level of confidence, which is equivalent to standardized normal deviate value of 1.96 and an acceptable margin of error of $5 \%$ (standard value of 0.05 ) (Table 1).

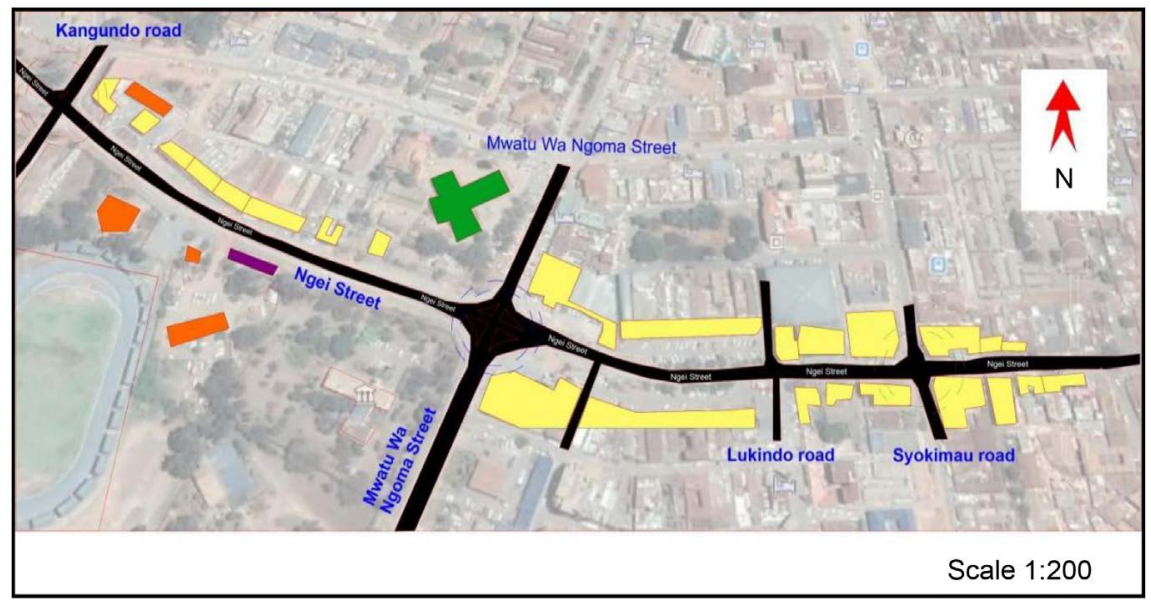

Figure 1. Study area (Ngei Street in Machakos Town). 


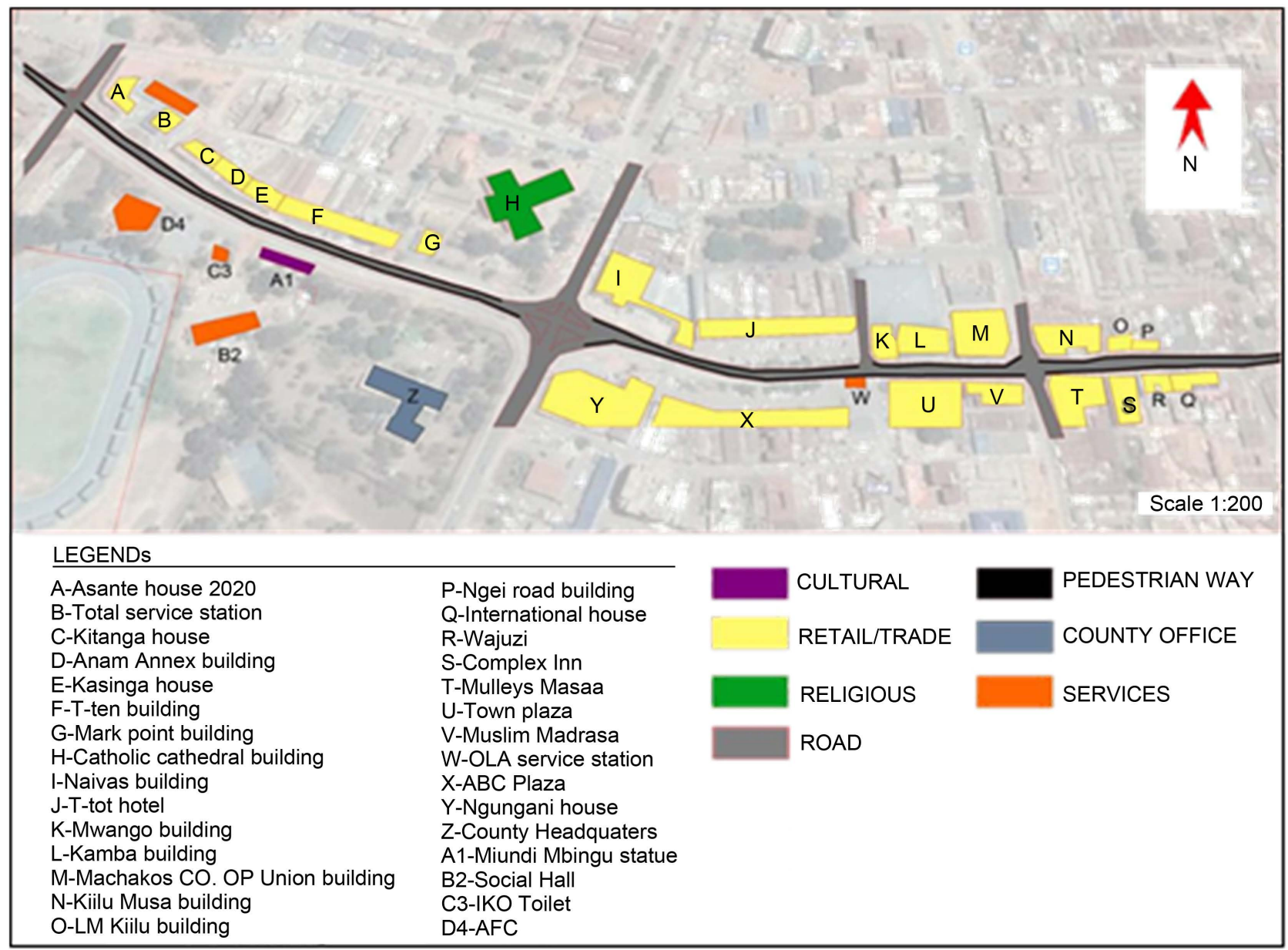

Figure 2. Coding of built environment.

Table 1. Main themes of survey questions.

\begin{tabular}{|c|c|c|c|}
\hline Criteria & $\begin{array}{c}\text { Groups of } \\
\text { questionnaire survey }\end{array}$ & $\begin{array}{c}\text { Type of } \\
\text { Responses }\end{array}$ & Description and Role \\
\hline $\begin{array}{l}\text { The demographic } \\
\text { characteristics }\end{array}$ & Respondents personal information & Choice and Open & $\begin{array}{l}\text { To understand the social } \\
\text { demographic attributes of the } \\
\text { study respondents }\end{array}$ \\
\hline Accessibility & $\begin{array}{l}\text { Are the walkways wide enough for walking? } \\
\text { Are the walkway paving surface broken? } \\
\text { Are the utility poles well placed along the walkway? } \\
\text { Are the walkways level changes even? } \\
\text { Are the feeder roads to the street narrow and congested? }\end{array}$ & Likert Scale & $\begin{array}{l}\text { To understand respondents' } \\
\text { knowledge on the physical } \\
\text { characteristics of the street's walkways } \\
\text { and how it could } \\
\text { affect walkability of the street. }\end{array}$ \\
\hline Congestion & $\begin{array}{l}\text { Are there hawkers' activities taking place along the walkway? } \\
\text { Are there stalls placed along the street which encroach } \\
\text { on to the walkway? } \\
\text { Are designated parking bays shared with pedestrian } \\
\text { walkways or cars parked on walkways? }\end{array}$ & Likert Scale & $\begin{array}{l}\text { To understand respondents } \\
\text { awareness of activities along Ngei } \\
\text { street as well as the attitude towards } \\
\text { the same on walkability of the street. }\end{array}$ \\
\hline Cleanliness & $\begin{array}{l}\text { Is there construction materials dumped along the walkway? } \\
\text { How do you rate the maintenance of walkways? } \\
\text { Do you experience waterlogging on the walkways } \\
\text { during the rainy season? }\end{array}$ & Likert Scale & $\begin{array}{l}\text { To understand respondents' } \\
\text { attitude on how cleanliness may } \\
\text { affect walkability of Ngei street. }\end{array}$ \\
\hline
\end{tabular}




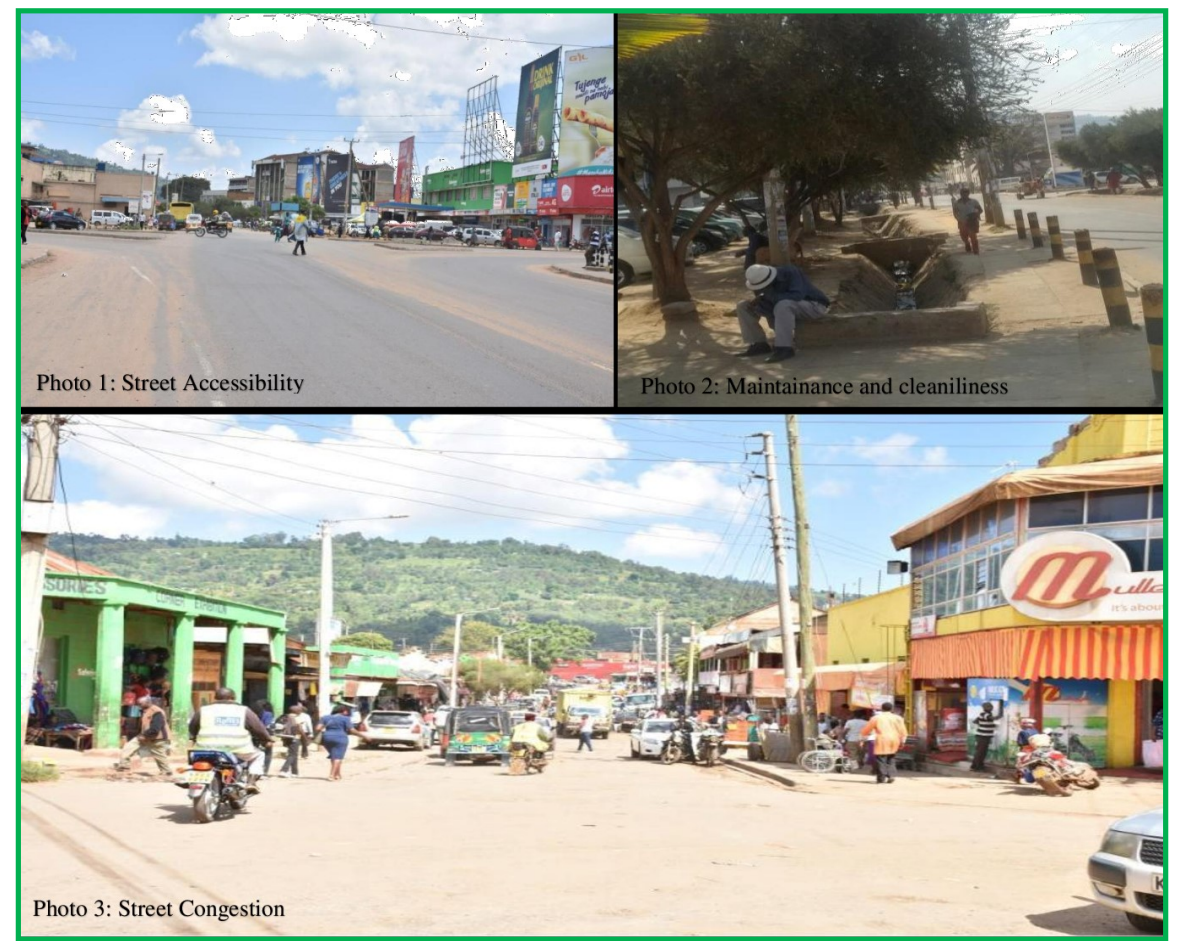

Figure 3. Photographic representation of the street.

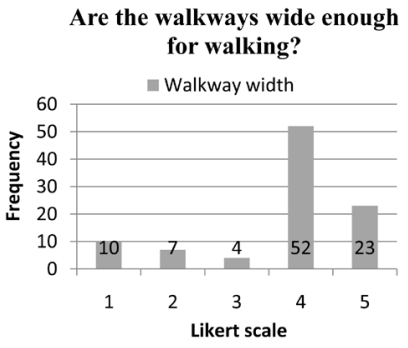

Are the utility poles well placed along the walkway?

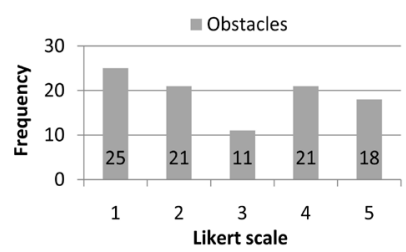

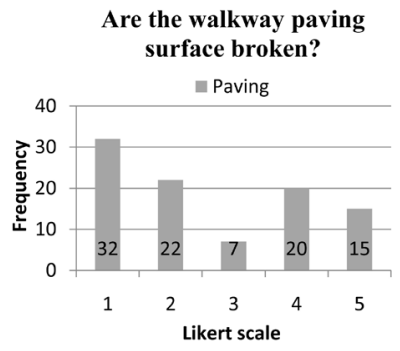

Are the walkways level changes even?

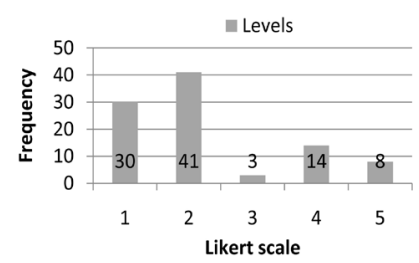

Figure 4. Graphical representation of study respondent's on accessibility of Ngei Street.

\subsection{Data Collection}

Before data collection, the researcher trained enumerators on the contents of data collection tools (questionnaires, photography, and observation); sampling techniques; ethical considerations for the study; research objectives, and how to ensure quality and consistency of data collected from respondents. Data collection exercise started on 10/12/2019 to 20/12/2019 with a pretesting exercise of questionnaires, and arising issues were addressed. During the actual data collection 
exercise, the principal researcher ensured quality control by monitoring performance of enumerators and evaluating completeness of filled questionnaires. These checks served to provide detection of errors and reliability of data collected.

\subsection{Statistical Analysis}

The authors used computer-aided statistical packages to conduct data analysis. The Statistical Package for Social Scientists (SPSS) series 24 and Microsoft Excel Software were in particular was used for analysis. First, all questionnaires were investigated for completeness and consistency to ensure reliability of data collected, then a numerical coding of the qualitative responses was done to for analysis and storage. The numerical codes entered into SPSS were run to achieve various objectives of this study. Data analysis involved simple descriptive statistics such as frequency counts and percentages to summarize the data and inferential statistics such as correlation analysis to determine how social demographic attributes of respondents affected their responses.

\section{Results and Discussion}

Table 2 presents a summary of the social demographic of the study respondents. Majority of the respondents were male, with $60 \%$ and $40 \%$ female. This is due to the population dynamics of the township, whereby the male population is the majority. This was also observed by the researcher having the majority of the pedestrians along the street understudy to be male. According to Makau et al. (2018), gender is a good predictor of perception studies because different genders perceive issues differently. Rather than the primary education, residents within the township have other skills that enable them get their daily living. However, majority of the respondents accounting for $58 \%$ of the sample population had attained the college level in various institutions with a variety of certifications achieved.

Table 2. Social demographics.

\begin{tabular}{ccc}
\hline Characteristic & Category & Percentage \\
\hline Gender & Male & 60 \\
\hline Age & Female & 40 \\
\hline & $18-24$ & 26 \\
& $25-34$ & 50 \\
\hline Education & $35-44$ & 6 \\
& $45-54$ & 13 \\
& $>55$ & 3 \\
& Primary & 4 \\
& Secondary & 6 \\
\hline
\end{tabular}


The level of education helped the respondents to understand the researcher's questionnaire and answer accordingly with minimal assistance. The ages of those interviewed ranged from 18 years to 58 yrs. Majority of those interviewed were between the age of 25 years to 34 years, representing $50 \%$ of those interviewed. The researcher observed majority of the pedestrians were young and formed the active members of the community with the ability to walk.

\subsection{Street Physical Characteristics and Accessibility}

In the survey, five measures were used to capture the degree of accessibility that users derived from the street's walking experience: walkway width, broken paving surface, obstacles by utility poles, uneven level changes, and feeder roads. Equally important were user responses to close-ended questions suggesting that accessibility was important in relation to walking.

Alfonzo (2005) suggests that the first-order need for walking is accessibility. Besides individual factors, choosing mobility, time, and other responsibilities may limit the viability of any strolling or destination-oriented walking trip. This study is concerned with the Street wideness, which supports walking. The larger part of the street has the driveway and walkway wide enough to offer good walking conditions except for the area between the cooperative bank and open-air market stretch, which has a narrow driveway.

Street configuration, pedestrian width, discontinuous pedestrian flow, paving materials affects the volume of pedestrians for comfortable walking (Kang, 2017). Wide roads and higher traffic speeds tend to create barriers to walking, thus often conflicting street design goals for vehicles and pedestrians. Paving materials and pedestrian width were selected in this study according to the pedestrian flow that allows for easy access. According to Saeed \& Furlan (2017), a minimum of $2.5 \mathrm{~m}$ to $4 \mathrm{~m}$ walkway without front zone and furniture area in mixed-use to high-intensity commercial area is recommended for barrier-free walking.

Walking conditions are affected by the quantity and quality of the footpaths, crosswalks and paths, connectivity of the path system, safety, and attractiveness of pedestrian facilities. I found out from the users that the paving surface was in good condition except for a few sections of the street with broken paving slabs and removed cabro and generally making the walkways conducive to the pedestrians. Moudon et al. (1996) found that in a community with pedestrian-friendly streets, walking is three times more common than in otherwise comparable communities that are less conducive to foot travel.

Measures to encourage walking will need to include some large-scale improvements to infrastructure, but overall this will only be successful if less high-profile measures are also given attention. For example, adequate funding for maintenance will be essential to ensure that issues such as cracked paving stones, puddles caused by blocked drains, utility poles on the walkways and broken lights do not dissuade people from walking. Similarly, where significant investment is made in an area's pedestrian environment, the intended increase in walking may occur unless accompanied by measures to promote vehicular roads. 
Street segments were characterized by detailed field surveys of the pedestrian quality attributes that have been shown to affect navigation in urban environments through their impact on the perceptions of pedestrians. As depicted in Figure 5, majority of pedestrians who responded on the questionnaire, 51\% felt that the street was wide and accessible. The results show that densities of movement increase with increased width of the walkways and maintenance of the sidewalks along the segments that is according to the researcher's observation. Like many other urban areas, Machakos has invested heavily in car-centered development, construction, and the expansion of road networks. With little consideration of pedestrians and other road users' this has led to high congestion in urban streets. As evident, with $47 \%$ of the respondent strongly agreeing of the congestion experienced in Ngei Street has persistently been unaddressed by the relevant agencies (Figure 5). Promoting combinations of more public transit, cycling, and walking reduce congestion in some urban areas and this should be borrowed to combat the situation in Machakos Town.

\subsection{Street Congestion}

The usefulness of the walkway is the environment's ability to satisfy the basic everyday needs of the individual for shopping, safely cross from one store to the other, and entertainment, and this ability or lack of it affects walking attitude. Usefulness translates the general land-use diversity to make it meaningful to the individual whose walking needs are considered. Further, it was found that hawkers were displaying their goods on the walkway. This has rendered most of the walking area to be vending places leaving pedestrians with small or no room for walking. The same is noted with build stalls and storefronts encroaching to the walkways

A further important factor related to walking attitude is perceived safety from traffic. Studies on real and perceived traffic safety suggest the importance of many measures and physical features, such as reducing street width and speed limits,

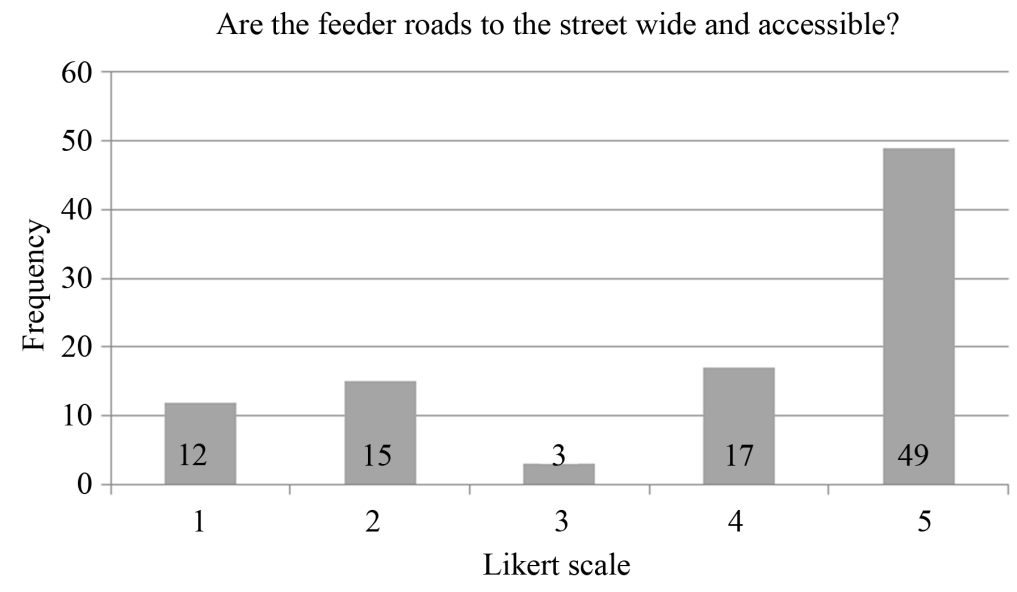

Figure 5. Wide and accessible feeder roads. 
introducing calming measures for traffic, curbside parking, trees or plantings to reduce or slow down traffic, separating pedestrians from fast-moving vehicles, making street crossing safer for pedestrians, and segregation of parking bays and the walkways (Mehta, 2008). This study found that $68.8 \%$ of the respondents strongly agreed that most sections of the streetcars were being parked on the walkways, which obstructed pedestrians and eventually had to use the roadway (Figure 6).

\subsection{Street Maintenance and Cleanliness}

On maintenance and cleanliness of the street, 56\% of the respondent confirmed that the area under study is well maintained and clean. On the contrary, the conditions of some pedestrian walkways are uneven, broken, and inadequate from support facilities and accessibility for persons with disabilities, which have a negative impact on Ngei Street walkability, as shown in Figure 7.

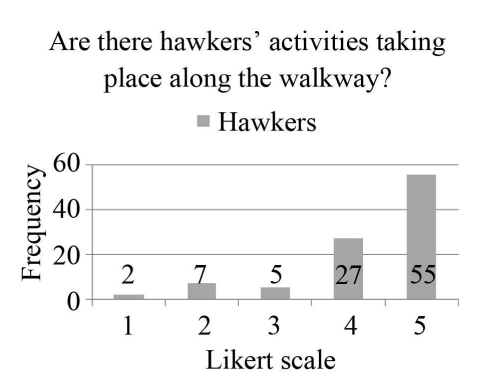

Are there stalls placed along the street which encroach on to the walkway?

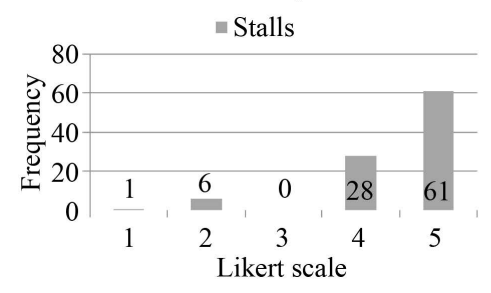

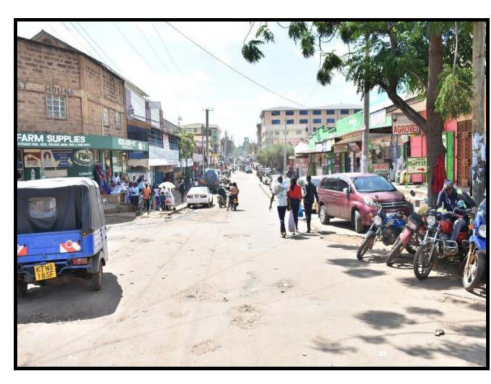

Are designatedd parking bays shared with pedestrian walkways or car parked on walkway? - Parking

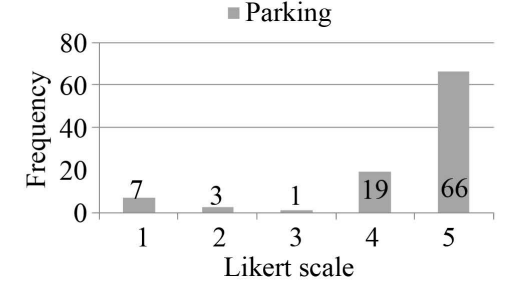

Figure 6. Photographic and graphical presentation of respondent's perception on Ngei Street congestion.

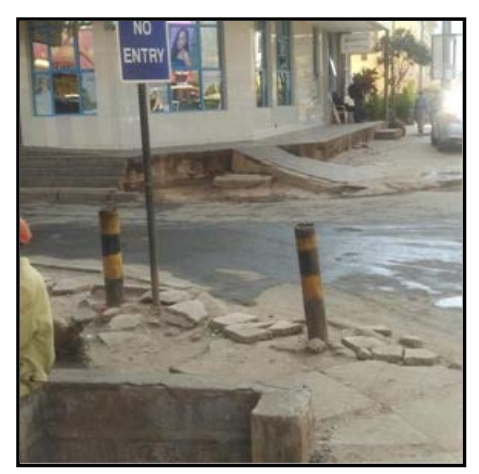

Is there construction materials dumped along the walkway?

$$
\text { - Construction }
$$

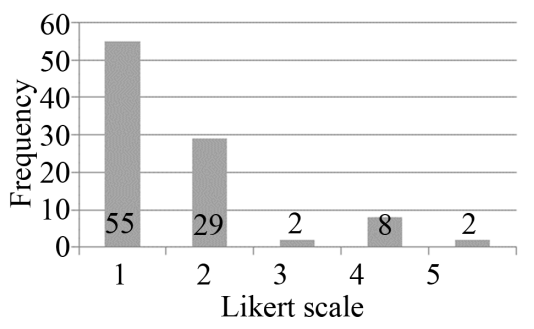

Figure 7. Street status. 
While the sense of walking is affected by the built environment, it also affects the real and perceived safety of pedestrians. As indicated in Figure 7 above, $57.3 \%$ of the respondent felt that the walkways adjacent to the construction sites where free from debris dumping which favored there errands in the street with the rest of the respondents $30.2 \%$ in disagreement, $2.1 \%$ neutral, $8.3 \%$ agreeing and $7.1 \%$ strongly agreeing.

This study found that associations with individuals, places, and events contribute to a sense of community familiarity and belonging. Places that help shape pedestrians' attitudes, provide continuity from past to present, often cater for ordinary but essential day-to-day functions, and help to establish the identity of their community, become meaningful to neighbors and attain a social value and significance.

This study also found out that the proper drainage on the walkways, which prevents waterlogging are all important to provide a useful, safe, comfortable, pleasurable and meaningful setting for walking in urban public spaces such as Ngei Street. It was also found that the association between the condition of the walkway of the Ngei Street and walking behavior, not only as a way of accessing different parts of the street but also the overall experience that it offers to the pedestrian (Figure 8).

\section{Conclusion and Recommendations}

Walkable streets support a sense of walking as an alternative to driving to reduce the town's vehicle congestion, and walking is also promoted as a fair means of transportation for people of different ages and classes. For Ngei Street or other commercial streets in the town, the lessons from this study are particularly important. Research findings confirmed by the pedestrian attitude identified facilities to improve walkability, including improvement and addition of non-continuous pedestrian walkways, availability of cheap pedestrian crossing across all street segments, traffic management to reduce vehicle congestion, periodic walkways maintenance, and regular pavement cleaning. This is in terms of policy and planning with key stakeholders (e.g., urban developers, landscape designers, landscape architects, architects) to build a pedestrian-friendly walkway per the need for a safe environment. The study further suggests that priority should be
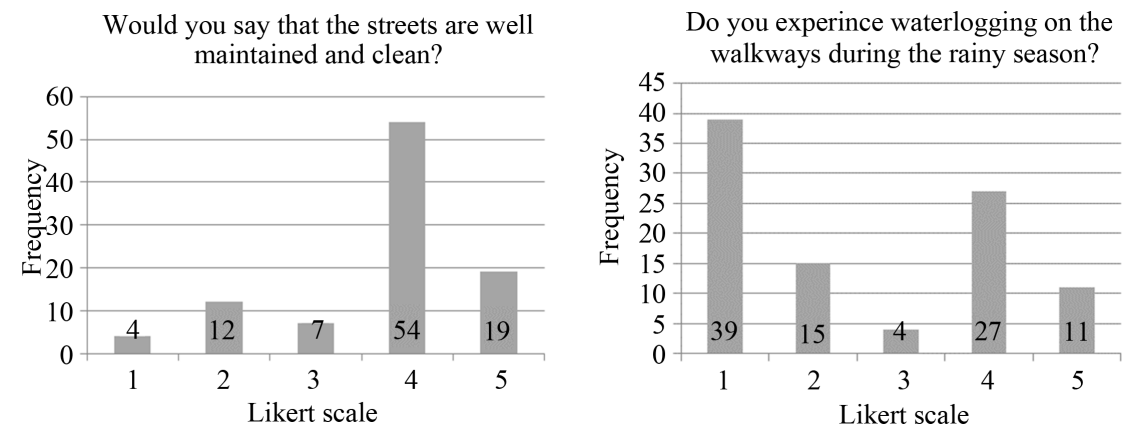

Figure 8. Perception of the cleanliness of Ngei Street. 
given to public participation to capture the needs and views of the people regarding certain elements of street design. Lastly, this paper opens a discussion on various topical issues related to contribution of street walkability to reduction of greenhouse gases and how county governments can tap on this opportunity going into the future to mitigate climate change. Further, the paper sets a foundation for amendment and development of new county ordinances that promote smart urban designs that promote non-motorized means of transport in our local towns.

\section{Acknowledgements}

The project leading to this publication has received support from various individuals: special thanks to Christopher K. Musembi for leading our team during data collection exercise. The authors thank in earnest, Anthony M. Makau for proofreading and editing our manuscript and his indispensable role during the publication process. Lastly, we thank Machakos County government for allowing us to use Machakos town as our study area.

\section{Conflicts of Interest}

The authors have not declared any conflict of interest regarding this publication.

\section{References}

Alfonzo, M. (2005). To Walk or Not to Walk? The Hierarchy of Walking Needs. Environment and Behavior, 37, 808-836. https://doi.org/10.1177/0013916504274016

Athanasios, G., Bortzoris, G., \& Elious, N. (2016). Pedestrian Road Safety in Relation to Urban Road Type and Traffic Flow. In 3rd CSUM (pp. 220-227). Volos: Elsevier B.V.

Bahari, I., Arshad. A., \& Yahya. Z. (2013). Assessing the Pedestrians' Perception of the Sidewalk Facilities Based on Pedestrian Travel Purpose. Malaysia: Research Management Institute. https://doi.org/10.1109/CSPA.2013.6530008

Barkin, J. S. (2003). Realist Constructivism. International Studies Review, 5, 325-342. https://doi.org/10.1046/j.1079-1760.2003.00503002.x

Bodner, G. M. (1986). Constructivism: A Theory of Knowledge. Journal of Chemical Education, 63, 873. https://doi.org/10.1021/ed063p873

Cho, G., Rodríguez, D. A., \& Khattak, A. J. (2009). The Role of the Built Environment in Explaining Relationships between Perceived and Actual Pedestrian and Bicyclist Safety. Accident Analysis \& Prevention, 41, 692-702. https://doi.org/10.1016/j.aap.2009.03.008

Chu, X., Guttenplan, M., \& Baltes, M. R. (2004). Why People Cross Where They Do: The Role of Street Environment. Transportation Research Record, 1878, 3-10. https://doi.org/10.3141/1878-01

Costall, A., \& Still, A. (1989). Gibson's Theory of Direct Perception and the Problem of Cultural Relativism. Journal for the Theory of Social Behaviour, 19, 433-441. https://doi.org/10.1111/j.1468-5914.1989.tb00159.x

Coughenour, C. (2013). An Examination of Walk-Ability in the Las Vegas Metropolitan Area (p. 1815). UNLV Theses Dissertation, Professional Papers and Capstones.

Demuth, A. (2013). Perception Theories. Kraków: Trnavská univerzita.

Forsyth, A. (2015). What Is a Walkable Place? The Walkability Debate in Urban Design. 
Urban Design International, 20, 274-292. https://doi.org/10.1057/udi.2015.22

Fosnot, C. T. (2013). Constructivism: Theory, Perspectives, and Practice. New York: Teachers College Press.

Gehl, J. (2013). Cities for People. Washington DC: Island Press.

Gibson, J. J. (2014). The Ecological Approach to Visual Perception: Classic Edition. East Sussex: Psychology Press. https://doi.org/10.4324/9781315740218

Hass-Klau, C. (2014). The Pedestrian and the City. Abingdon-on-Thames: Routledge. https://doi.org/10.4324/9780203067390

Johansson, G. (1970). On Theories for Visual Space Perception: A Letter to Gibson. Scandinavian Journal of Psychology, 11, 67-74. https://doi.org/10.1111/j.1467-9450.1970.tb00719.x

Kang, C. (2017). Measuring the Effects of Street Network Configurations on Walking in Seoul, Korea. Cities, 71, 30-40. https://doi.org/10.1016/j.cities.2017.07.005

Knill, D. C., \& Richards, W. (1996). Perception as Bayesian inference. Cambridge: Cambridge University Press. https://doi.org/10.1017/CBO9780511984037

Litman, T. A. (2016). Evaluating Transportation Land Use Impacts: Considering the Impacts, Benefits and Costs of Different Land Use Development Patterns (Vol. 1). Victoria: Victoria Transport Policy Institute.

Lynch, K. (1960). The Image of the City. Cambridge, MS: MIT Press.

Makau, A. M., Mukundi, J. B., Ochieng'Adimo, A., Gichuhi, M. W., \& Wesonga, J. (2018). Perception and Mitigation Preferences on Climate Change among Residents of Nairobi City County. African Journal of Environmental Science and Technology, 12, 244-257. https://doi.org/10.5897/AJEST2018.2508

Mehta, V. (2008). Walkable Streets: Pedestrian Behavior, Perceptions and Attitudes. Journal of Urbanism: International Research on Placemaking and Urban Sustainability, 1, 217-245. https://doi.org/10.1080/17549170802529480

Montgomery, J. (1998). Making A City: Urbanity, Vitality and Urban Design. The Journal of Urban Design, 3, 93-116. https://doi.org/10.1080/13574809808724418

Moudon, A. V., Hess, P. M., Snyder, M. C., \& Stanilov, K. (1996). Effects of Site Design on Pedestrian Travel in Mixed Use, Medium-Density Environments. Document WA-RD 432.1, Washington DC: Washington State Transportation Center. https://doi.org/10.3141/1578-07

Quednau, R. (2018). Why Walkable Streets Are More Economically Productive. Strong Towns Article.

Ramachandran, V. (1990). Interactions between Motion, Depth, Color and Form: The Utilitarian Theory of Perception. In C. Blakemore (Ed.), Vision: Coding and Efficiency (pp. 346-360). Cambridge: Cambridge University Press. https://doi.org/10.1017/CBO9780511626197.033

Reed, E. S. (1988). James J. Gibson and the Psychology of Perception. London: Yale University Press. https://doi.org/10.2307/j.ctt1xp3nmm

Robbins, S. E. (2000). Bergson, Perception and Gibson. Journal of Consciousness Studies, 7, 23-45.

Saeed, M. H., \& Furlan, R. (2017). Strategies for the Enhancement of Users' Interactions in Al Mirqab Al Jadeed Street in Doha, State of Qatar. Architecture Research, 7, 69-83.

Shaaban, K. (2019). Assessing Sidewalks and Corridor Walkability in Developing Countries. Sustainability, 11, 3865. https://doi.org/10.3390/su11143865 
Shapley, R., Caelli, T., Grossberg, S., Morgan, M., \& Rentschler, I. (1990). Computational Theories of Visual Perception. In L. Spillmann, \& J. S. Werner (Eds.), Visual Perception: The Neurophysiological Foundations (pp. 417-448). Amsterdam: Elsevier. https://doi.org/10.1016/B978-0-12-657675-7.50021-1

Sisiopiku, V. P., \& Akin, D. (2003). Pedestrian Behaviors at and Perceptions towards Various Pedestrian Facilities: An Examination Based on Observation and Survey Data. Transportation Research Part F: Traffic Psychology and Behaviour, 6, 249-274. https://doi.org/10.1016/j.trf.2003.06.001

Thornton, M. A., \& Mitchell, J. P. (2018). Theories of Person Perception Predict Patterns of Neural Activity during Mentalizing. Cerebral Cortex, 28, 3505-3520. https://doi.org/10.1093/cercor/bhx216

Tibbalds, F. (2012). Making People-Friendly Towns: Improving the Public Environment in Towns and Cities. Abingdon-on-Thames: Taylor \& Francis. https://doi.org/10.4324/9780203469521

Wang, W., Li, P., Wang, W., \& Namgung, M. (2012). Exploring Determinants of Pedestrians' Satisfaction with Sidewalk Environments: Case Study in Korea. Journal of Urban Planning and Development, 138, 166-172. https://doi.org/10.1061/(ASCE)UP.1943-5444.0000105 